$146: 103-106$.

18. Donovan TJ, Ward M, Shephard RW. Evaluation of endoscopic sclerosis of esophageal varices in children. $J$ Pediatr Gastroenterol Nutr 1986; 5 : 696-700.

19. Wolfe BM, Atkinson JB, Wooley MM. Treatment of esophageal varices by sclerotherapy in children. Am J Surg 1983; 146 : 103-106.

20. Johnson D, Vane DW, Boles ET, Clatworthy HW. Esophageal sclerotherapy : an effective modality in children. $J$ Pediatr Surg 1985; $20: 703-707$.

21. Eleftheriadis E. Duodenal varices after sclerotherapy for esophageal varices. $\mathrm{Am}$ J Gastroenterol 1988; 83 : 439-441.
22. Azmy AA. Bleeding rectal varices following injection sclerotherapy of esophageal varices in a child. $Z$ Kinderchir 1987; 42 : 252.

23. Lebrec D, Benhamou JP. Ectopic varices in portal hypertension. Clin Gastroenterol $1985 ; 14: 105-121$.

24. Hyun BH, Varga CF, Rubin RJ. Spontaneous and pathologic rupture of the spleen. Arch Surg 1972; 104 : 652-657.

25. Mowat AP. Prevention of variceal bleeding. I Pediatr Gastmenterol Nutr 1986, 5 : 679-681.

26. Kumar A, Broor SL. Benign strictures of the esophagus. Tropical Gastroenterol $1988 ; 9: 169-178$.

\title{
The Rights of the Child
}

The United Nations Convention on the Rights of the Child has been adopted by the UN General Assembly on 20 November 1989. The adoption was unanimous, the drafting process having already taken nearly 10 years.

Shorn of its legal language, the sayings of the Convention can be summarized in ten simple principles :

1. All children have equal rights without discrimination of race, religion or nationality.

2. The right to special protection for full physical, mental and social development.

3. The right to a name and nationality.

4. The right to adequate nutrition, housing, recreation and medical services.

5. The right of special care for the physically and mentally handicapped.

6. The right to affection, love and understanding.

7. The right to a free education, play and recreation.

8. The right to be among the first to receive protection and relief.

9. The right to be protected against neglect, cruelty and exploitation.

10. The right to be brought up in a spirit of tolerance, peace and universal brotherhood.

Abstracted from Future 1989; 26-27: 30, 41. 